\title{
EVALUASI DATA CLIMATE HAZARDS GROUP INFRARED PRECIPITATION WITH STATION (CHIRPS) DENGAN DATA PEMBANDING AUTOMATIC WEATHER STATIONS (AWS) DALAM MENGESTIMASI CURAH HUJAN HARIAN DI PROVINSI PAPUA BARAT
}

\section{CLIMATE HAZARDS GROUP INFRARED PRECIPITATION WITH STATION (CHIRPS) DATA EVALUATION WITH AUTOMATIC WEATHER STATIONS (AWS) COMPARISON DATA IN ESTIMATING DAILY RAIN IN WEST PAPUA PROVINCE}

\author{
Budiyono $^{1}$ dan Arif Faisol ${ }^{2 凶}$ \\ ${ }^{1}$ Prodi D3 Budidaya Tanaman Perkebunan, Fakultas Pertanian, Universitas Papua \\ ${ }^{2}$ Prodi Teknik Pertanian dan Biosistem, Fakultas Teknologi Pertanian, Universitas Papua \\ ${ }^{\circledR}$ Komunikasi Penulis, email: arif.unipa@gmail.com \\ DOI:http://dx.doi.org/10.23960/jtep-l.v10i1.64-72
}

Naskah ini diterima pada 26 Desember 2020; revisi pada 15 Februari 2021; disetujui untuk dipublikasikan pada 3 Maret 2021

\begin{abstract}
This research aims to evaluate the CHIRPS data in estimating daily rainfall in West Papua compared with automatic weather stations (AWS) data recording. The data used in this research are daily CHIRPS data and AWS daily data recording 1996 to 2020 from AWS Rendani-Manokwari, AWS Jefman-Raja Ampat, AWS Torea-Fakfak, and AWS Kaimana-Kaimana. CHIRPS data were evaluated using the Point to Pixel method based on numerical and categorical parameters i.e., root mean square error (RMSE), mean error (ME), mean absolute error (MAE), Pearson correlation (r), probability of detection (POD), critical success index (CSI), and T-test. The research showed that CHIRPS had a significant difference to AWS data in estimating daily rainfall in West Papua based on a T-test. However CHIRPS has a moderate accuracy in estimating daily rainfall in West Papua with RMSE $=8.59$ $\mathrm{mm}, M E=2.75 \mathrm{~mm}$, and $M A E=5.15 \mathrm{~mm}$ and had a moderate positive correlation with AWS data with $r=0.43$. Besides, CHIRPS has good accuracy in detecting rain events in West Papua indicated by a POD =0.72 and CSI = 0.43. Therefore, CHIRPS data can be used as an alternative solution for providing rainfall data in West Papua.
\end{abstract}

Keywords: satellite observation, rainfall predictor, point to pixel

\begin{abstract}
ABSTRAK
Penelitian ini bertujuan untuk mengevaluasi data CHIRPS dalam mengestimasi curah hujan harian di Provinsi Papua Barat. Data yang digunakan pada penelitian ini adalah data CHIRPS harian dan data hujan harian perekaman tahun 1996 - 2020 yang diperoleh dari 4 (empat) automatic weather stations (AWS), yaitu; AWS RendaniKabupaten Manokwari, AWS Jefman-Kabupaten Raja Ampat, AWS Torea-Kabupaten Fakfak, dan AWS KaimanaKabupaten Kaimana. Evaluasi dilakukan dengan membandingkan data hujan CHIRPS dengan data AWS menggunakan metode point to pixel berdasarkan parameter numerik dan parameter kategorial. Parameter numerik yang digunakan untuk mengevaluasi yaitu; root mean square error (RMSE), mean error (ME), mean absolute error (MAE), korelasi Pearson (r), dan uji-T. Sedangkan parameter kategorial yang digunakan untuk mengevaluasi data CHIRPS adalah probability of detection (POD) dan critical success index (CSI). Hasil penelitian menunjukkan bahwa data CHIRPS memiliki perbedaan nilai yang signifikan terhadap data AWS, namun data CHIRPS memiliki akurasi yang cukup baik dalam mengestimasi curah hujan harian di Provinsi Papua Barat yang ditunjukkan dengan nilai $\mathrm{RMSE}=8,59 \mathrm{~mm}, \mathrm{ME}=2,75 \mathrm{~mm}$, dan $\mathrm{MAE}=5,15 \mathrm{~mm}$ serta memiliki korelasi yang cukup kuat terhadap data AWS dengan nilai $r=0,43$. Disamping itu CHIRPS cukup baik dalam mendeteksi peristiwa hujan yang terjadi di Papua Barat yang ditunjukkan dengan nilai POD =0,72 dan CSI =0,43. Sehingga CHIRPS dapat digunakan sebagai solusi alternatif untuk menyediakan data hujan di Provinsi Papua Barat.
\end{abstract}

Kata Kunci: pengamatan satelit, prediktor hujan, point to pixel 


\section{PENDAHULUAN}

Curah hujan merupakan salah satu parameter utama pada bidang pertanian. Informasi curah hujan digunakan untuk menilai kesesuaian lahan dalam pengembangan lahan pertanian (Ritung et al, 2011), perencanaan irigasi dan bangunan air (Hydrology Subcommittee, 1982; Dirjen Sumber Daya Air, 2013), estimasi dan monitoring kekeringan (Ebrahimpour et al., 2014; Chattopadhyay et al., 2020), dan sebagainya.

Pada umumnya curah hujan diukur menggunakan rain gauge atau dikenal dengan pluviometer, ombrometer, dan hygrometer. Metode ini hanya menghasilkan informasi hujan berupa titik (point measurement) dengan tingkat keterwakilan spasial yang rendah. Disamping itu World Meteorological Organization (WMO) (2010) merekomendasikan bahwa stasiun pengamat cuaca atau iklim hanya dapat digunakan untuk mewakili suatu wilayah seluas $100 \mathrm{~km}^{2}-1000$ $\mathrm{km}^{2}$.

Berdasarkan data dari Badan Meteorologi, Klimatologi, dan Geofisika (BMKG) (2018) jumlah stasiun penangkar hujan di Provinsi Barat sebanyak 16 stasiun, stasiun iklim sebanyak 7 stasiun, dan automatic weather stations (AWS) sebanyak 6 stasiun. Jika merujuk pada rekomendasi WMO, maka Provinsi Papua Barat yang memiliki luas $\pm 102.946 \mathrm{~km}^{2}$ (Badan Pusat Statistik, 2020) idealnya memiliki 103 stasiun penangkar hujan maupun stasiun iklim.

Saat ini telah tersedia data hujan hasil pengamatan satelit. Disamping memiliki wilayah liputan yang sangat luas, data hujan hasil pengamatan satelit memiliki akurasi yang cukup baik karena telah dikalibrasi dengan stasiun pengamat hujan yang ada di bumi. Beberapa contoh data hujan hasil perekaman satelit antara lain; Tropical Rainfall Measuring Mission (TRMM), Climate Hazards Group Infrared Precipitation with Stations (CHIRPS), Global Precipitation Measurement (GPM), Global Rainfall Map (GSMap), CPC Morphing Technique (CMORPH), CICS High-Resolution Optimally Interpolated Microwave Precipitation from Satellites (CHOMPS), Daily Surface Weather and Climatological Summaries (Daymet), Global
Precipitation Climatology Centre (GPCC), Global Precipitation Climatology Project (GPCP), Precipitation Estimation from Remotely Sensed Information using Artificial Neural Networks Climate Data Record (PERSIANN-CDR), Asian Precipitation - Highly-Resolved Observational Data Integration Towards Evaluation (APHRODITES), dan The Climatologies at high resolution for the Earth's land surface (CELSA) (National Center for Atmospheric Research Staff, 2020).

Data CHIRPS merupakan salah satu data hujan berbasis satelit yang telah dimanfaatkan oleh beberapa lembaga di dunia untuk mengestimasi data hujan, diantaranya; Climate Hazards Centre - University of California memanfaatkan data CHIRPS untuk mengestimasi dan memantau curah hujan di Afrika, Afrika Timur, Afrika Barat, Afrika Selatan, kawasan Asia Tengah, Amerika Selatan, Amerika Tengah, dan Haiti (Climate Hazards Center, 2020), International Research Institute for Climate and Society Colombia University memanfaatkan data CHIRPS untuk memprediksi curah hujan di Indonesia dan beberapa wilayah lainnya (International Research Institute for Climate and Society, 2015), dan Lembaga Penerbangan dan Antariksa Nasional (LAPAN) memanfaatkan citra satelit untuk memantau curah hujan di Indonesia (LAPAN, 2020).

CHIRPS mengkombinasikan data pengamatan satelit, data observasi pada stasiun hujan, serta prediktor dalam mengestimasi curah hujan (Funk et al, 2014). CHIRPS menyediakan data hujan perekaman tahun 1981 hingga saat ini dengan durasi harian, 5 harian, 10 harian, bulanan, 2 bulanan, dan 3 bulanan pada resolusi spasial $5 \mathrm{~km}$ (Funk et al., 2014). Beberapa peneliti telah menguji akurasi CHIRPS, diantaranya Gebrechorkos et al. (2018) dan Dinku et al. (2018) melaporkan bahwa CHIRPS sangat akurat dalam membangkitkan informasi curah hujan di Afrika Timur dibandingkan dengan data hasil pengamatan pada stasiun hujan. CHIRPS juga memiliki akurasi yang bagus dalam mengestimasi curah hujan di Iran (Saeidizand et al., 2018). Penelitian yang dilakukan oleh Trejo et al. (2016) menunjukkan bahwa data hujan bulanan minimum di Venezuela yang diestimasi dari CHIRPS cenderung 
overestimation dan curah hujan bulanan maksimum yang diestimasi dari CHIRPS cenderung underestimation. Penelitian yang dilakukan oleh Faisol et al. (2020) menunjukkan bahwa CHIRPS cukup akurat dalam mengestimasi curah hujan harian di Jawa Timur dengan tingkat penyimpangan sebesar $11,41 \%$ dibandingkan data hasil pengamatan pada AWS.

Berdasarkan kondisi tersebut, penelitian ini bertujuan untuk mengevaluasi data CHIRPS dalam mengestimasi curah hujan harian di Provinsi Papua Barat agar dapat dipertimbangkan sebagai solusi alternatif dalam penyediaan data hujan di Provinsi Papua Barat akibat terbatasnya stasiun penangkar hujan dan stasiun iklim.

\section{BAHAN DAN METODE}

Penelitian ini dilakukan di Provinsi Papua Barat yang terletak pada $1^{\circ} 12^{\prime} 07^{\prime \prime} \mathrm{LU}-4^{\circ} 24^{\prime} 04^{\prime \prime} \mathrm{LS}$ dan 129¹4‘11“ BT - 1355'33“BT. Lokasi penelitian ditunjukkan pada Gambar 1. Secara umum penelitian ini terdiri atas 4 (empat) tahapan utama, yaitu; inventarisasi data, ekstraksi data, seleksi data, dan evaluasi data. Diagram alir penelitian disajikan pada Gambar 2.

\subsection{Inventarisasi Data}

Tahapan ini bertujuan untuk melakukan inventarisasi data CHIRPS dan data hujan perekaman tahun 1996 sampai tahun 2020 yang diperoleh dari 4 (empat) AWS, yaitu AWS Rendani-Kabupaten Manokwari, AWS JefmanKabupaten Raja Ampat, AWS Torea-Kabupaten Fakfak, dan AWS Kaimana-Kabupaten Kaimana. Lokasi AWS di Provinsi Papua Barat disajikan pada Gambar 3.

\subsection{Ekstraksi data}

Tahapan ini bertujuan untuk mengekstrak data hujan CHIRPS berdasarkan lokasi stasiun AWS menggunakan metode point to pixel.

\subsection{Seleksi data}

Tahapan ini bertujuan untuk menyeleksi data hujan yang layak digunakan dengan cara mempertahankan data atau membuang data sehingga diperoleh data yang konsisten. Seleksi data dilakukan dengan membuang data yang kosong serta data yang secara numerik berbeda jauh dengan data lainnya atau data outlier. Pada tahapan ini juga dilakukan analisis homogenitas untuk mengetahui keragaman antara. Data outlier dihitung menggunakan persamaan berikut:

$$
x>\mu \pm 3 \sigma
$$

Keterangan: $x$ adalah data outlier $(\mathrm{mm}), \mu$ adalah nilai rerata data hujan $(\mathrm{mm})$, dan $\sigma$ adalah nilai penyimpangan standar data hujan $(\mathrm{mm})$.

\subsection{Evaluasi data}

Tahapan ini bertujuan untuk membandingkan data CHIRPS dan data hujan hasil perekaman pada AWS. Performa CHIRPS diuji berdasarkan parameter numerik dan parameter kategorial. Parameter numerik yang digunakan untuk mengevaluasi data CHIRPS, yaitu; root mean square error (RMSE), mean error (ME), mean absolute error (MAE), serta korelasi Pearson ( $\mathrm{r}$ ). Sedangkan parameter kategorial yang digunakan untuk mengevaluasi data CHIRPS adalah probability of detection (POD) dan critical success index (CSI). Parameter tersebut dihitung menggunakan persamaan berikut:

$$
R M S E=\frac{1}{n} \sum_{i=1}^{n}\left(y_{i}-x_{i}\right)^{2}
$$

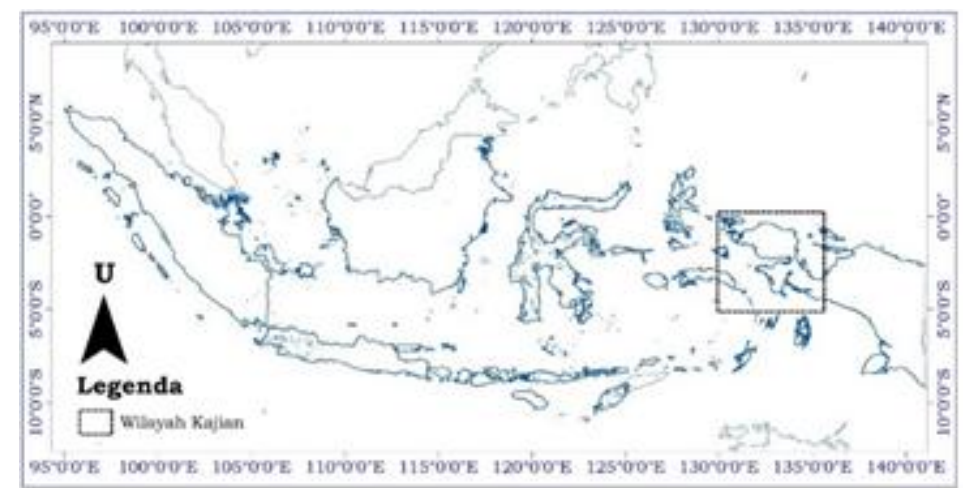

Gambar 1. Wilayah Kajian 


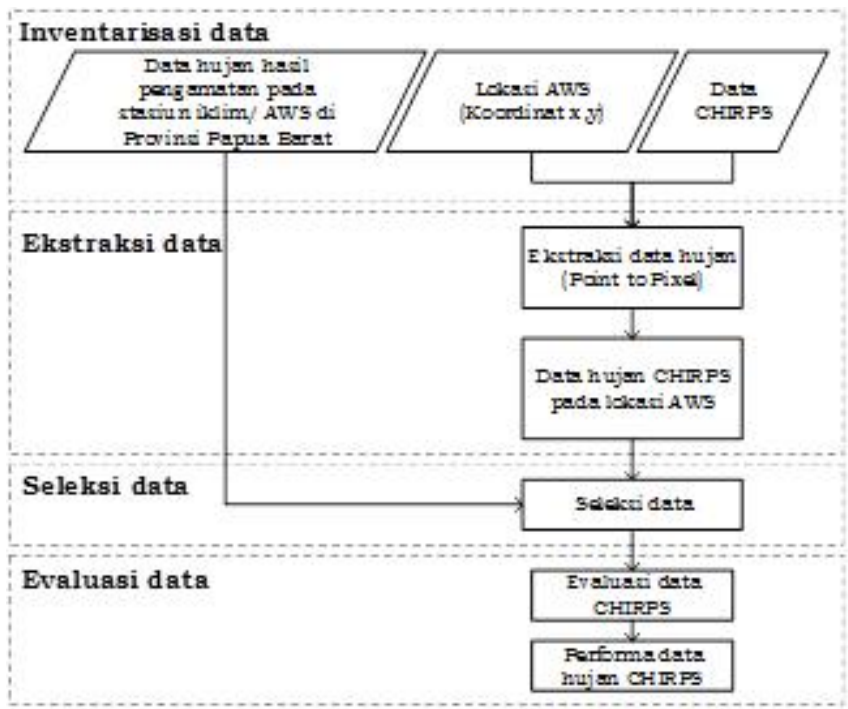

Gambar 2. Diagram Alir Penelitian

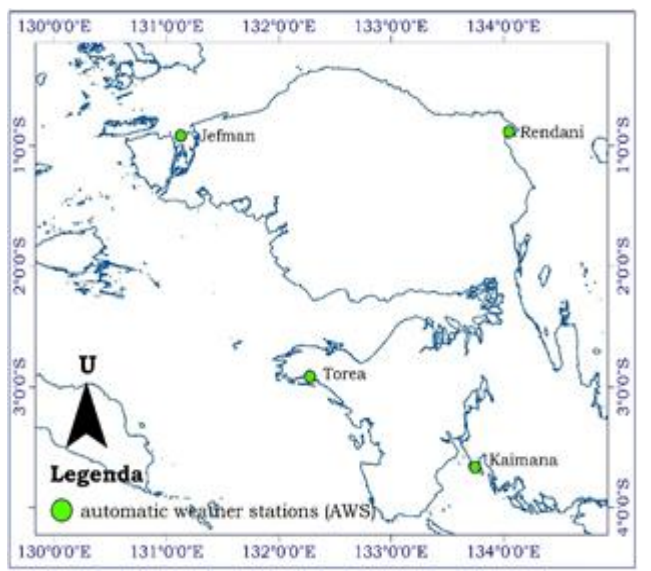

Gambar 3. Lokasi Automatic Weather Stations

$$
\begin{gathered}
M E=\frac{1}{n} \sum_{i=1}^{n}\left(y_{i}-x_{i}\right) \\
M A E=\frac{1}{n} \sum_{i=1}^{n}\left|y_{i}-x_{i}\right| \\
r=\frac{\sum_{i=1}^{n}(y i-\bar{y})(x i-\bar{x})}{\sqrt{\sum_{i=1}^{n}(y i-\bar{y})^{2}} \sqrt{\sum_{i=1}^{n}(x i-\bar{x})^{2}}}
\end{gathered}
$$

Keterangan: RMSE adalah root mean square error, ME adalah mean error, MAE adalah mean absolute error, r adalah nilai korelasi Pearson, $\mathrm{y}_{\mathrm{i}}$ adalah nilai curah hujan dari citra satelit pada waktu ke-i (mm), $\bar{y}$ nilai curah hujan rerata dari citra satelit pada periode tertentu $(\mathrm{mm}), \mathrm{x}_{\mathrm{i}}$ nilai curah hujan perekaman AWS pada waktu ke-i (mm), $\bar{x}$ nilai curah hujan rerata perekaman AWS pada periode tertentu $(\mathrm{mm})$, dan $\mathrm{n}$ adalah jumlah data. Nilai terbaik dari RMSE, ME, dan MAE adalah 0 , dan nilai terbaik $r$ adalah 1 . (Omranian et al., 2018; Saeidizand et al., 2018; Lelis et al., 2018; Wang et al, 2017; Javier et al., 2016).

$$
\begin{aligned}
P O D & =\left(\frac{H}{H+M}\right) \\
C S I & =\left(\frac{H}{H+M+F}\right)
\end{aligned}
$$

Keterangan: $H$ adalah banyaknya kejadian hujan yang terdeteksi oleh CHIRPS dan AWS; $M$ adalah banyaknya kejadian hujan yang terdeteksi oleh AWS namun tidak terdeteksi oleh CHIRPS; dan $F$ adalah banyak kejadian hujan yang terdeteksi oleh CHIRPS namun tidak terdeteksi oleh AWS. Nilai terbaik dari POD = 1 dan CSI = 1 (Sungmin et al, 2017; Wang et al., 2017; Javier et al., 2016; Meyer et al., 2017; Wei et al, 2018; Prakash et al., 2017).

Dalam menentukan kejadian hujan pada CHIRPS dan AWS digunakan ambang batas 0,5 mm (Sungmin et al., 2017; Wei et al., 2018). Tabel 1 menyajikan kontingensi untuk mengevaluasi kejadian hujan. 
Data CHIRPS juga dianalisis menggunakan uji T berpasangan (paired T-tes) untuk mengetahui signifikansi perbedaan antara data CHIRPS dan data AWS. Persamaan yang digunakan pada uji T adalah sebagai berikut (Machiwal \& Jha, 2012; Nuryadi et al., 2017):

$$
t s=\frac{\left|\overline{x_{2}}-\overline{x_{1}}\right|}{\sqrt{\frac{\left(n_{1}-1\right) s_{1}^{2}+\left(n_{2}-1\right) s_{2}^{2}}{n_{1}+n_{2}-2}\left(\frac{1}{n_{1}}+\frac{1}{n_{2}}\right)}}
$$

Keterangan : ts adalah nilai uji $\mathrm{T}, \mathrm{S}_{1}$ adalah nilai variansi kelompok $1, S_{2}$ adalah nilai variansi kelompok $2, \mathrm{n}_{1}$ adalah banyaknya data kelompok 1 , dan $n_{2}$ adalah banyaknya data kelompok 2 .

Uji T dilakukan pada tingkat signifikansi (level of significance) sebesar $5 \%$ atau $\propto=0,05$. Jika nilai uji $\mathrm{T}\left(\mathrm{T}_{\text {hitung }}\right)>$ nilai kritis $\left(\mathrm{T}_{\text {tabel }}\right)$ maka terdapat perbedaan yang signifikan antara data CHIRPS dan data AWS. Namun, jika nilai uji T $\left(\mathrm{T}_{\text {hitung }}\right)<$ nilai kritis $\left(\mathrm{T}_{\text {tabel }}\right)$ maka tidak terdapat perbedaan yang signifikan antara data CHIRPS dan data AWS.

\section{HASIL DAN PEMBAHASAN}

Data CHIRPS dapat menggambarkan distribusi hujan di Provinsi Papua Barat dengan sangat baik. Hal ini disebabkan CHIRPS memiliki resolusi spasial yang cukup tinggi, yaitu sebesar $5 \mathrm{~km}$. Distribusi hujan di Provinsi Papua Barat pada tanggal 29 - 30 November 2020 berdasarkan data CHIRPS ditunjukkan pada Gambar 4.

Disamping dapat menggambarkan distribusi hujan dengan baik, data CHIRPS memiliki akurasi yang cukup baik dalam mengestimasi curah hujan harian di Provinsi Papua Barat dibandingkan data AWS yang ditunjukkan dengan nilai $\mathrm{RMSE}=8,59 \mathrm{~mm}, \mathrm{ME}=2,75 \mathrm{~mm}, \mathrm{MAE}=$ 5,15 serta memiliki korelasi yang cukup kuat terhadap data AWS dengan nilai $r=0,43$. Hasil penelitian ini relevan dengan penelitian yang dilakukan oleh Faisol et al. (2020) bahwa CHIRPS cukup akurat dalam mengestimasi curah hujan harian di Jawa Timur dengan nilai ME = $0,31 \mathrm{~mm}$ dan $r=0,40$. Hasil evaluasi data CHIRPS

Tabel 1. Tabel Kontingensi untuk Mengevaluasi Kejadian Hujan

\begin{tabular}{|c|c|c|}
\hline $\begin{array}{ll}\text { AWS } & \text { CHIRPS } \\
\end{array}$ & $\begin{array}{c}\text { Hujan } \\
(\text { curah hujan }=0,5 \mathrm{~mm})\end{array}$ & $\begin{array}{c}\text { Tidak hujan } \\
\text { (curah hujan }<0,5 \mathrm{~mm})\end{array}$ \\
\hline $\begin{array}{c}\text { Hujan } \\
(\text { curah hujan }=0,5 \mathrm{~mm})\end{array}$ & Hits $(H)$ & Misses (M) \\
\hline $\begin{array}{c}\text { Tidak hujan } \\
\text { (curah hujan }<0,5 \mathrm{~mm} \text { ) }\end{array}$ & False alarms $(F)$ & Correct negatives \\
\hline
\end{tabular}

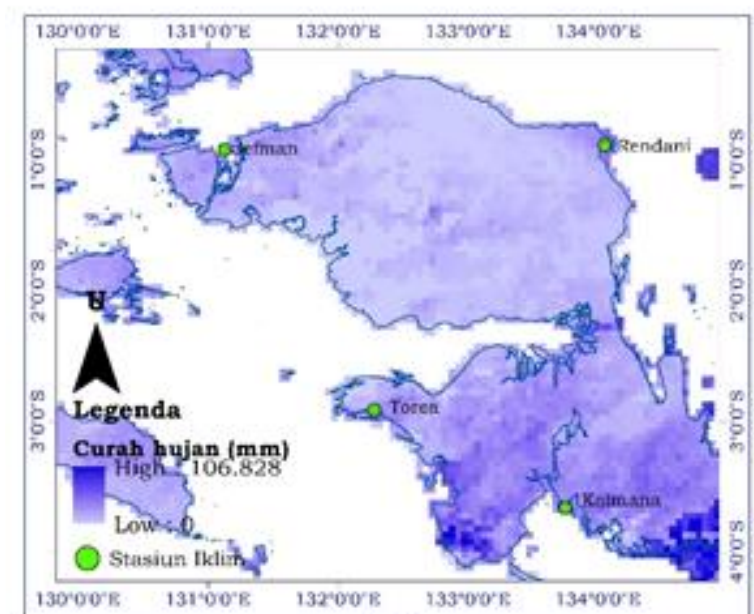

(a)

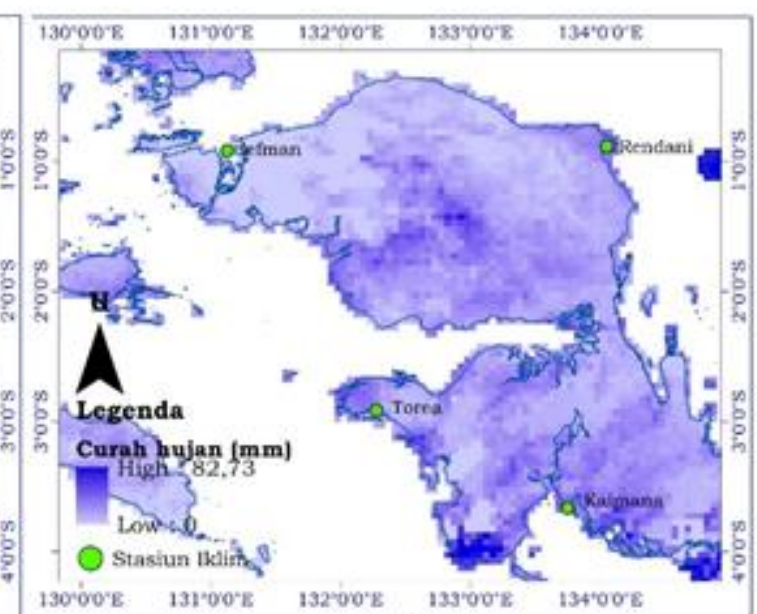

(b)

Gambar 4. Distribusi Hujan di Provinsi Papua Barat (a) 29 November 2020 dan (b) 30 November 2020 
dalam mengestimasi data hujan harian di Provinsi Papua Barat dibandingkan data AWS berdasarkan parameter numerik disajikan pada Tabel 2.

Meskipun data CHIRPS cukup akurat dalam mengestimasi curah hujan harian di Provinsi Papua Barat, namun data CHIRPS memiliki perbedaan yang signifikan terhadap data AWS. Hasil uji T berpasangan antara data CHIRPS dan data AWS pada tingkat signifikansi sebesar 5\% disajikan pada Tabel 3.
Ditinjau dari parameter kategorial, CHIRPS memiliki akurasi yang cukup baik dalam mendeteksi peristiwa hujan di Papua Barat yang ditunjukkan dengan nilai POD $=0,74$ dan CSI $=$ 0,42 . Hasil ini relevan dengan hasil penelitian yang dilakukan oleh Faisol et al. (2020) yaitu CHIRPS memiliki nilai POD $=0,67$ dan CSI $=0,45$ dalam mendeteksi peristiwa hujan harian di Jawa Timur. Hasil evaluasi parameter kategorial data CHIRPS dalam mengestimasi data hujan harian di Provinsi Papua Barat dibandingkan data AWS disajikan pada Tabel 4.

Tabel 2. Hasil Evaluasi Parameter Numerik Data CHIRPS

\begin{tabular}{cccccc}
\hline Parameter & $\begin{array}{c}\text { AWS Rendani } \\
\text { Manokwari }\end{array}$ & $\begin{array}{c}\text { AWS Jefman } \\
\text { Raja Ampat }\end{array}$ & $\begin{array}{c}\text { AWS Torea } \\
\text { Fakfak }\end{array}$ & $\begin{array}{c}\text { AWS Kaimana } \\
\text { Kaimana }\end{array}$ & Rerata \\
\hline RMSE & 7,79 & 8,68 & 9,84 & 8,05 & 8,59 \\
ME & 2,47 & 2,57 & 3,12 & 2,84 & 2,75 \\
MAE & 4,33 & 5,23 & 6,23 & 4,81 & 5,15 \\
r & 0,42 & 0,54 & 0,43 & 0,33 & 0,43 \\
\hline
\end{tabular}

Tabel 3. Hasil Uji T Berpasangan Antara Data AWS dan CHIRPS

\begin{tabular}{|c|c|c|c|c|}
\hline Parameter Lokasi & $\begin{array}{c}\text { Rendani } \\
\text { Manokwari }\end{array}$ & $\begin{array}{c}\text { Jefman } \\
\text { Raja Ampat }\end{array}$ & $\begin{array}{c}\text { Torea } \\
\text { Fakfak }\end{array}$ & $\begin{array}{l}\text { Kaimana } \\
\text { Kaimana }\end{array}$ \\
\hline Jumlah data & 5940 & 6554 & 7067 & 6556 \\
\hline$\alpha$ & 0,05 & 0,05 & 0,05 & 0,05 \\
\hline Rata-rata AWS & 2,26 & 3,69 & 3,78 & 2,23 \\
\hline Rata-rata CHIRPS & 4,74 & 6,25 & 6,89 & 5,07 \\
\hline Standar deviasi AWS & 6,03 & 8,45 & 8,45 & 5,96 \\
\hline Standar deviasi CHIRPS & 7,47 & 8,75 & 9.19 & 7,00 \\
\hline T-tabel & 1,64 & 1,64 & 1,64 & 1,64 \\
\hline T-hitung & 25,79 & 25,02 & 28,12 & 30,61 \\
\hline
\end{tabular}

Tabel 4. Hasil Evaluasi Parameter Kategorial Data CHIRPS

\begin{tabular}{lccccc}
\hline Parameter & $\begin{array}{c}\text { AWS Rendani } \\
\text { Manokwari }\end{array}$ & $\begin{array}{c}\text { AWS } \\
\text { Jefman } \\
\text { Raja Ampat }\end{array}$ & $\begin{array}{c}\text { AWS } \\
\text { Torea } \\
\text { Fakfak }\end{array}$ & $\begin{array}{c}\text { AWS } \\
\text { Kaimana } \\
\text { Kaimana }\end{array}$ & Rerata \\
\hline POD & 0,70 & 0,74 & 0,73 & 0,72 & 0,72 \\
CSI & 0,42 & 0,49 & 0,46 & 0,33 & 0,43 \\
\hline
\end{tabular}

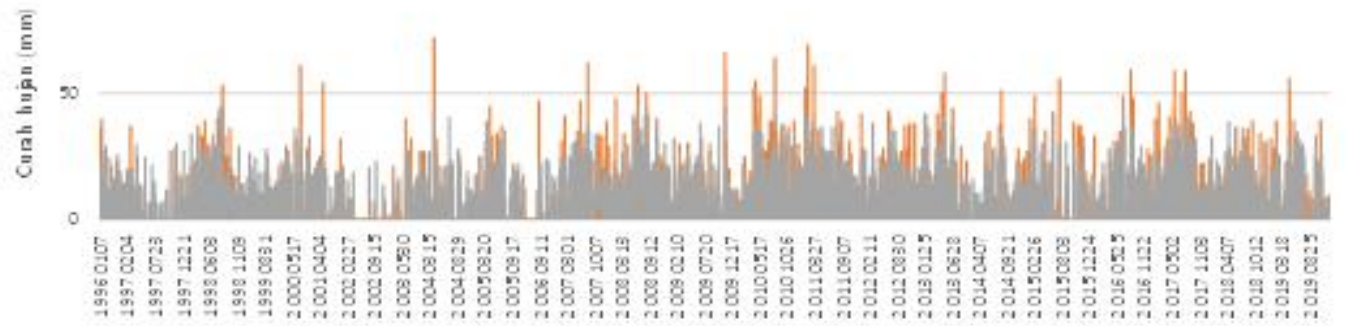

Gambar 5. Grafik Perbandingan Data Curah Cujan Harian CHIRPS dan AWS Jefman-Kabupaten Raja Ampat Perekaman 1996-2020 


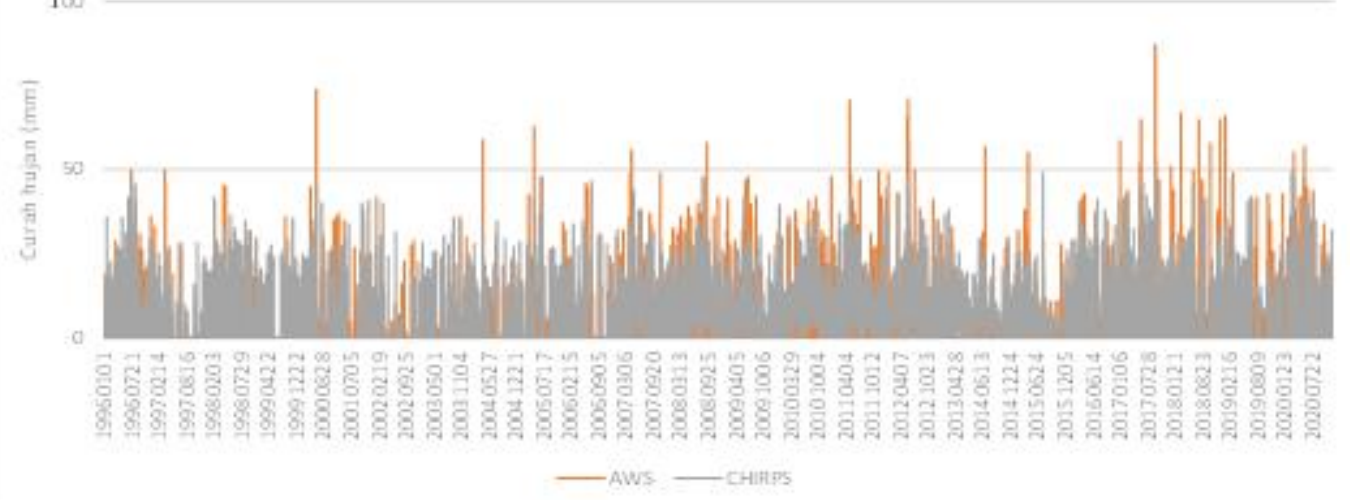

Gambar 6. Grafik Perbandingan Data Curah hujan Harian CHIRPS dan AWS Torea-Kabupaten Fakfak Perekaman 1996 - 2020

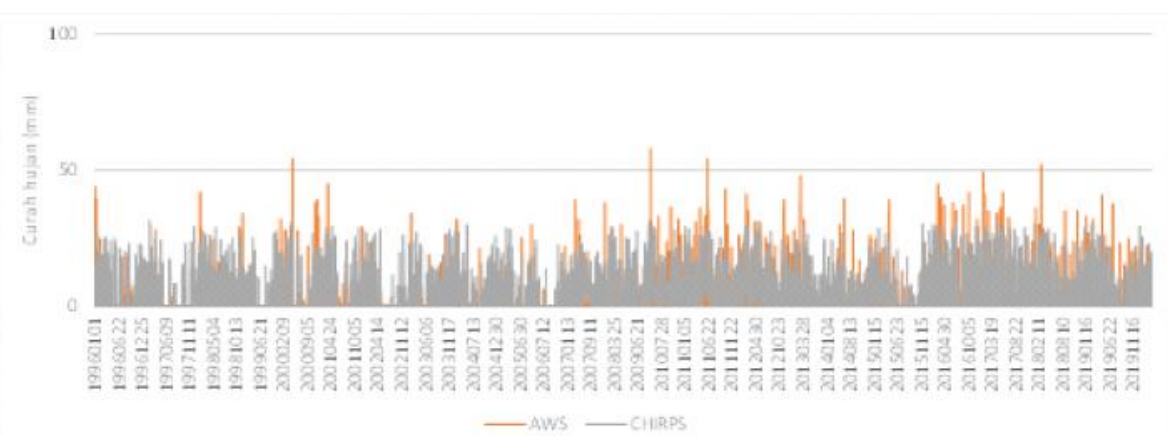

Gambar 7. Grafik Perbandingan Data Curah Hujan Harian CHIRPS dan AWS Kaimana - Kabupaten Kaimana Perekaman 1996 - 2020

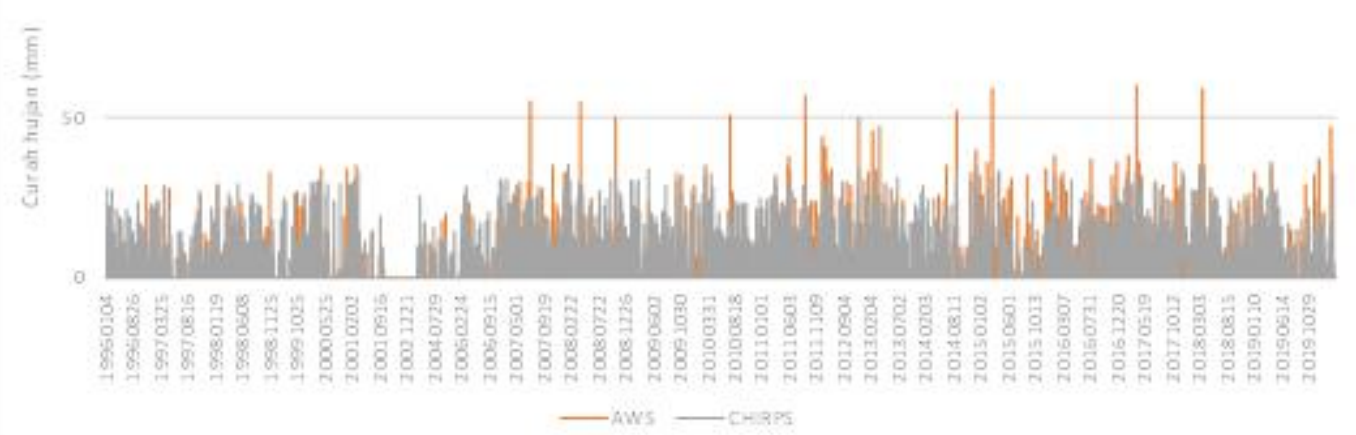

Gambar 8. Grafik Perbandingan Data Curah Hujan Harian CHIRPS dan AWS Rendani - Kabupaten Manokwari Perekaman 1996 - 2020

Pada umumnya data CHIRPS cenderung underestimated dalam mengestimasi curah hujan harian di Provinsi Papua Barat dibanding data AWS. Kondisi ini relevan dengan hasil penelitian yang dilakukan oleh Trejo et al. (2016), Gebrechorkos et al. (2018), dan Faisol et al. (2020). Komparasi antara data CHIRPS dan data AWS perekaman 1996 - 2020 disajikan pada Gambar 5 - Gambar 8.

\section{KESIMPULAN DAN SARAN}

Data CHIRPS cukup akurat dalam mengestimasi dan mendeteksi curah hujan harian di Provinsi Papua Barat meskipun memiliki perbedaan yang signifikan terhadap data AWS. Sehingga data CHIRPS dapat dipertimbangkan sebagai solusi alternatif dalam penyediaan data hujan di Provinsi Papua akibat keterbatasan stasiun penangkar hujan dan stasiun iklim. 


\section{DAFTAR PUSTAKA}

Badan Pusat Statistik. 2020. Provinsi Papua Barat Dalam Angka 2020. Badan Pusat Statistik.

BMKG. 2018. Metadata Stasiun. https:// d a t a o n l i n e.b m k g.go.i d / mcstation_metadata

Chattopadhyay, N., Malathi, K., Tidke, N., Attri, S. D., \& Ray, K. 2020. Monitoring agricultural drought using combined drought index in India. Journal of Earth System Science, 129(1): 16. https://doi.org/10.1007/ s12040-020-01417-w.

Climate Hazards Center. 2020. CHC Early Estimates. https://www.chc.ucsb.edu/ monitoring/early-estimates.

Dinku, T., Funk, C., Peterson, P., Maidment, R., Tadesse, T., Gadain, H., \& Ceccato, P. 2018. Validation of the CHIRPS Satellite Rainfall Estimates over Eastern of Africa/ : Validation of the CHIRPS Satellite Rainfall Estimates Over Eastern. Quarterly Journal of the Royal Meteorological Society, 144(April). https://doi.org/ 10.1002/qj.3244

Dirjen Sumber Daya Air. 2013. Standar Perencanaan Irigasi KP-02: Kriteria Perencanaan Bagian Bangunan Utama (2nd ed.). Kementerian Pekerjaan Umum.

Ebrahimpour, M., Rahimi, J., Nikkhah, A., \& Bazrafshan, J. 2014. Monitoring Agricultural Drought Using the Standardized Effective Precipitation Index. Journal of Irrigation and Drainage Engineering, 141(1): 1-9. https:// doi.org/10.1061/(ASCE)IR.19434774.0000771 .

Faisol, A., Indarto, I., Novita, E., \& Budiyono, B. 2020. Komparasi Antara Climate Hazards Group Infrared Precipitation With Stations (CHIRPS) dan Global Precipitation Measurement (GPM) Dalam Membangkitkan Informasi Curah Hujan Harian di Provinsi Jawa Timur. Jurnal
Teknologi Pertanian Andalas, 24(2): 148156.

Funk, C. C., Peterson, P. J., Landsfeld, M. F., Pedreros, D. H., Verdin, J. P., Rowland, J. D., Romero, B. E., Husak, G. J., Michaelsen, J. C., \& Verdin, A. P. 2014. A Quasi-Global Precipitation Time Series for Drought Monitoring (1st ed.).

Gebrechorkos, S. H., Hülsmann, S., \& Bernhofer, C. 2018. Evaluation of Multiple Climate Data Sources for Managing Environmental Resources in East Africa. Hydrology and Earth System Sciences, 22: 4547-4564. https://doi.org/https://doi.org/10.5194/ hess-22-4547-2018.

Hydrology Subcommittee. 1982. Guidelines for Determining Flood Flow Frequency/: Bulletin 17B.

International Research Institute for Climate and Society. 2015. Indonesia CPT Precipitation Forecast.https://iridl.ldeo.columbia.edu/ maproom/Agriculture/Forecast/ Indonesia_Precip_CHIRPS.html\#tabs-2

LAPAN. 2020. Curah Hujan. https:// spbn.pusfatja.lapan.go.id/maps/7122

Lelis, L. C., Bosquilia, R. W. D., \& Duarte, S. N. 2018. Assessment of Precipitation Data Generated by GPM and TRMM Satellites. Revista Brasileira de Meteorologia, 33(1): 153-163.

Machiwal, D., \& Jha, M. K. 2012. Hydrologic Time Series Analysis: Theory and Practice (1st ed.). Springer International Publishing.

Meyer, H., Drönner, J., \& Nauss, T. 2017. Satellitebased High-Resolution Mapping of Rainfall over Southern Africa. Atmospheric Measurement Techniques, 10, 2009-2019.

National Center for Atmospheric Research Staff. 2020. The Climate Data Guide: Precipitation Data Sets: Overview \& Comparison table. Agustus. https:// 
climatedataguide.ucar.edu/climate-data/ precipitation-data-sets-overviewcomparison-table.

Nuryadi, Astuti, T. D., Utami, E. S., \& Budiantara, M. 2017. Dasar-Dasar Statistik Penelitian (1st ed.). Sibuku Media.

Omranian, E., Sharif, H. O., \& Tvakoly, A. A. 2018. How Well Can Global Precipitation Measurement ( GPM ) Capture Hurricanes/? Case Study/ : Hurricane Harvey. Remote Sensing, 14. https:// doi.org/10.3390/rs10071150.

Prakash, S., Kumar, M. R. R., Mathew, S., \& Venkatesan, R. 2017. How Accurate are Satellite Estimates of Precipitation over The North Indian Ocean/ ? Theoretical and Applied Climatology, 9 p. https:// doi.org/https://doi.org/10.1007/s00704017-2287-2.

Ritung, S., Nugroho, K., Mulyani, A., \& Suryani, E. 2011. Petunjuk Teknis Evaluasi Lahan untuk Komoditas Pertanian (2nd ed.). Balai Besar Penelitian dan Pengembangan Sumberdaya Lahan Pertanian.

Saeidizand, R., Sabetghadam, S., Tarnavsky, E., \& Pierleoni, A. 2018. Evaluation of CHIRPS Rainfall Estimates over Iran. Advances in Remote Sensing Pf Rainfall and Snowfall, 144(May): 282-291. https://doi.org/ 10.1002/qj.3342.
Sungmin, O., Foelsche, U., Kirchengast, G., Fuchsberger, J., Tan, J., \& Petersen, W. A. 2017. Evaluation of GPM IMERG Early , Late, and Final rainfall estimates using WegenerNet gauge data in southeastern Austria. Hydrology and Earth System Science, 21: 6559-6572.

Trejo, F. J. P., Barbosa, H. A., Peñaloza-Murillo, M. A., Moreno, M. A., \& Farías, A. 2016. Intercomparison of Improved Satellite Rainfall Estimation with CHIRPS Gridded Product and Rain Gauge Data over Venezuela. Atmósfera, 29(4): 323-342. https: / / doi.org / 10.20937 / ATM.2016.29.04.04.

Wang, Z., Zhong, R., Lai, C., \& Chen, J. 2017. Evaluation of The GPM IMERG Satellitebased Precipitation Products and The Hydrological Utility. Atmospheric Research, 196(June): 151-163. https:// doi.org/10.1016/j.atmosres.2017.06.020.

Wei, G., Haishen, L., Crow, W. T., Zhu, Y., Wang, J., \& Su, J. 2018. TMPA Precipitation Products with Gauged Rainfall over Mainland China. Advances in Meteorology, 2018(4): 18 p.

World Meteorological Organization. 2010. Commission for Instruments and Methods of Observation (WMO-No. 1064). In Fifteenth session - Abridged final report with resolutions and recommendations (Issue 1064). http://www.wmo.int/ pages/prog/www/CIMO/CIM015WM01064/1064_en.pdf 